\title{
Peptide Utilization by Pseudomonas putida and Pseudomonas maltophilia
}

\author{
By T. CASCIERI, JR* AND M. F. MALLETTE \\ Department of Biochemistry, The Pennsylvania State University, \\ University Park, Pennsylvania 16802, U.S.A.
}

(Received 18 June 1975; revised II August 1975)

\begin{abstract}
SUMMARY
Pseudomonas putida assimilates peptides and hydrolyses them with intracellular peptidases. Amino acid auxotrophs (his, trp, thr or met) grew on a variety of di- and tripeptides up to twice as slowly as with free amino acids. Pseudomonas putida has separate uptake systems for both dipeptides and oligopeptides (three or more residues). Although the dipeptide system transported a variety of structurally diverse dipeptides it did not transport peptides having either unprotonatable $\mathrm{N}$-terminal amino groups, blocked C-terminal carboxyl groups, D-residues, three or more residues, $N$-methylated peptide bonds, or $\beta$-amino acids. Oligopeptide uptake lacked amino acid side-chain specificity, required a free $\mathrm{N}$-terminal L-residue and had an upper size limit. Glycylglycyl-I),L-p-fluorophenylalanine inhibited growth of $P$. putida. Uptake of glycylglycyl[ $\left[-{ }^{14} \mathrm{C}\right]$ alanine was rapid and inhibited by $2,4-$ dinitrophenol. Both dipeptide and oligopeptide uptake were constitutive. Dipeptides competed with oligopeptides for oligopeptide uptake, but oligopeptides did not compete in the dipeptide system. Final bacterial yields were 5 to 10 times greater when $P$. putida his was grown on histidyl di- or tripeptides rather than on free histidine because the histidyl residue was protected from catabolism by L-histidine ammonia-lyase.

Methionine peptides could satisfy the methionine requirements of $P$. maltophilia. Generation times on glycylmethionine and glycylmethionylglycine were equal to those obtained with free methionine. Methionylglycylmethionylmethionine gave a generation time twice that of free methionine. Growth of $P$. maltophilia was inhibited by glycylglycyl-D,L-p-fluorophenylalanine.
\end{abstract}

\section{INTRODUCTION}

Peptide transport has been used to introduce otherwise impermeant molecules into Salmonella typhimurium (Ames et al. 1973) and Escherichia coli (Fickel \& Gilvarg, 1973) after incorporating them into peptides. The peptide transport system has also been used to distinguish between amino acid transport mutants and metabolic mutants in these micro-organisms (Guardiola et al. 1974: Kustu \& Ames, 1973). The peptide uptake systems of Saccharomyces cerevisiae (Naider, Becker \& Katzir-Katchalski, 1974). Neurospora crassa (Wolfinbarger \& Marzluf, 1974) and the small intestine (Burston \& Matthews, 1972) are different from the procaryotic systems.

Peptide uptake has not been studied previously in Pseudomonas. Although Pseudomonas and Escherichia are both classified Gram-negative, Escherichia species are primarily gut inhabitants, whilst Pseudomonas species occur in a variety of environments and possess unusual nutritional versatility, some being able to use 100 quite different growth substrates.

* Present address: FMC Corporation, Industrial Chemical Division, Princeton, New Jersey 08540, U.S.A. 
Hence, many different metabolic pathways are potentially available within a single Pseudomonas strain. Pseudomonads are also unusual in their envelope compositions and are resistant to many antimetabolites which inhibit growth of other Gram-negative bacteria. Finally, some pseudomonads secrete extracellular proteases while Escherichia species do not.

The present study began with a search for peptide uptake in Pseudomonas putida and investigation of its specificities. Pseudomonas maltophilia was also examined because it possesses an extracellular protease. Peptide uptake by $P$. maltophilia would support the hypothesis that secreted proteases degrade host proteins to peptides which are then transported into the bacterium for hydrolysis and use in protein synthesis. Extracellular products, including proteases, contribute to the pathogenicities of some pseudomonads (Liu, 1966; Johnson, Morris \& Berk, 1967).

\section{METHODS}

Micro-organisms. Pseudomonas putida ATCCI 2633 was used, and P. putida met, his, thr and trp were obtained from Dr A. T. Phillips, Department of Biochemistry, The Pennsylvania State University. Pseudomonas maltophilia, obtained from Jefferson Medical College, Philadelphia, Pennsylvania, U.S.A., was isolated originally from a burn wound. Both organisms were grown in minimal medium $\mathrm{pH} 7 \cdot 0$, containing $(\mathrm{g} / \mathrm{l}):\left(\mathrm{NH}_{4}\right)_{2} \mathrm{SO}_{4}, \mathrm{I} \cdot 0 ; \mathrm{K}_{2} \mathrm{HPO}_{4}$, ${ }_{10} \cdot 5 ; \mathrm{KH}_{2} \mathrm{PO}_{4}, 4.5 ; \mathrm{MgSO}_{4} \cdot 7 \mathrm{H}_{2} \mathrm{O}, 0 \cdot \mathrm{I}$; sodium citrate (dihydrate), $0.5 ;$ glucose, $2 \cdot 0$. Peptides or amino acids, sterilized by membrane filtration, were added to this minimal medium.

Inocula were prepared by transferring a loopful of bacteria from a nutrient agar slant (brain-heart infusion agar for P. maltophilia) to $10 \mathrm{ml}$ of minimal medium containing any required additional nutrients in a metal-capped tube. Bacteria were grown at $30^{\circ} \mathrm{C}\left(37^{\circ} \mathrm{C}\right.$ for $P$. maltophilia) with shaking (200 rev./min) to an $E_{650}$ of 0.4 , and $0.1 \mathrm{ml}$ was subcultured from this tube into Io $\mathrm{ml}$ of the same medium and grown to the same extinction again. Such subcultures were used as sources of bacteria for experimental work.

Materials. Except as noted below, peptides and peptide derivatives were purchased from Schwarz/Mann (Orangeburg, New York, U.S.A.), Sigma or Cyclo (Los Angeles, California, U.S.A.). Amino acids, 2,4,6-trinitrobenzenesulphonate and lysozyme were purchased from Nutritional Biochemicals Corp. (Cleveland, Ohio, U.S.A.), PPO and dimethyl POPOP from Packard Instrument Co., and $\left[\mathrm{I}^{-14} \mathrm{C}\right]$ alanine was purchased from International Chemical and Nuclear Corp. (Cleveland, Ohio, U.S.A.). General reagents were standard grades obtained from laboratory supply companies.

$\alpha-N$-acetylglycylmethionine and $\alpha-N$-acetylglycylmethionylglycine were prepared according to Naider et al. (1974). Ethyl ester hydrochlorides of amino acids and peptides were prepared with thionyl chloride in ethanol (Brenner \& Huber, 1953).

Glycylglycyl $\left[\mathrm{I}-{ }^{14} \mathrm{C}\right]$ alanine was prepared by coupling $\left[\mathrm{I}^{14} \mathrm{C}\right]$ alanine ethyl ester hydrochloride with benzyloxycarbonylglycylglycine using I-ethyl-3-(3-dimethylaminopropyl)carbodiimide (Sheehan, Preston \& Cruickshank, 1965). Blocking groups were removed simultaneously with II M- $\mathrm{HCl}$ according to Merrifield \& Woolley (1956).

Glycylglycyl-D,L-p-fluorophenylalanine, glycylglycylmethionine and methionylglycylglycine were prepared (Anderson, Zimmerman \& Callahan, 1967) by reacting anhydrides of benzyloxycarbonylglycylglycine, $t$-butyloxyglycine and $t$-butyloxymethionine with ethyl ester hydrochlorides of $\mathrm{D}, \mathrm{L}-p$-fluorophenylalanine, glycylmethionine and glycylglycine respectively. Purity of peptides and peptide derivatives was checked by: (i) silica gel thin-layer chromatography using either I-butanol-acetic acid-water $(4: \mathrm{I}: \mathrm{I}$, by vol.) or I-butanol-acetone-acetic acid- $\mathrm{NH}_{4} \mathrm{OH}$-water (I8:6:4:I:II, by vol.) and (ii) paper chromatography on Whatman 
$3 \mathrm{MM}$ paper using $\mathrm{I}$-butanol-4M M- $\mathrm{NH}_{4} \mathrm{OH}$ ethanol ( $\mathrm{I}: 8: 4$, by vol.), in ascending direction. Purity of peptide derivatives was also checked by high voltage electrophoresis in pyridineacetic acid-water ( $1: 10: 89$, by vol.) at $\mathrm{pH} 3.5$ on Whatman $3 \mathrm{MM}$ paper (40 to $50 \mathrm{~V} / \mathrm{cm}$ ). Compounds having free amino groups were detected with $0.5 \%(\mathrm{w} / \mathrm{v})$ ninhydrin in acetone, followed by heating for $3 \mathrm{~min}$ at 100 ' C. If there were no free amino groups, compounds were detected by exposure to $I_{2}$ vapour.

Peptide uptake studies with amino acid auxotrophs. Auxotrophs, grown in minimal media supplemented with the required amino acid ( 0.1 to $0.2 \mathrm{~mm}$ ), were harvested by centrifuging for $10 \mathrm{~min}$ at $10000 \mathrm{~g}$ and $4{ }^{\circ} \mathrm{C}$, washed twice with volumes of cold salts solution equal to those of the original growth media, and centrifuged. The bacteria were suspended in $\mathrm{I} 0 \mathrm{ml}$ of minimal medium only and incubated 15 to $45 \mathrm{~min}$ at $30^{\circ} \mathrm{C}$ to exhaust any endogenous amino acid required by the auxotroph. The wash procedure alone proved sufficient to remove endogenous histidine from the his mutant. Portions $(0.2 \mathrm{ml})$ of these bacterial suspensions were added to $10 \mathrm{ml}$ of minimal medium containing the peptide to be tested at the designated concentration (generally 0.05 to $0.3 \mathrm{~mm}$ ). Growth was then followed by extinction measurements at $650 \mathrm{~nm}$. Pseudomonas maltophilia has a growth requirement for methionine. Growth studies performed with this micro-organism were analogous to those with the $P$. putida auxotrophs, except that no starvation period was required to exhaust endogenous methionine, and bacteria were grown at $37 \mathrm{C}$. Unless otherwise indicated, growth studies were repeated at least once. Controls were inoculated into minimal medium.

Growth inhibition by glycylglycy/-D,1-p-fluorophenylalanine. In analogous studies, either glycylglycyl-D,L-p-fluorophenylalanine or D,L-p-fluorophenylalanine was added before inoculation to minimal medium, together with the amino acid needed by an auxotroph before inoculation.

Uptake of glycylglycyl[ $\left[{ }^{14} \mathrm{C}\right]$ alanine. Uptake was measured by the method of Britten \& McClure (1962). Pseudomonas putida was grown, washed, suspended at $2.5 \times 10^{9}$ bacteria $/ \mathrm{ml}$, incubated for $30 \mathrm{~min}$ at $25^{\circ} \mathrm{C}$, and peptide was added. At short time intervals, portions $(2.0 \mathrm{ml})$ were collected on Millipore filters $(0.45 \mu \mathrm{m}$ pore size $)$, washed immediately with $5 \mathrm{ml}$ of minimal medium at $25^{\circ} \mathrm{C}$, and allowed to dry. A standard control contained no cells. Filters were counted 10 min for ${ }^{14} \mathrm{C}$ with a Beckman LS-150 scintillation counter in $1 \mathrm{ml}$ ethylene glycol monomethyl ether plus $10 \mathrm{ml}$ toluene containing $0.5 \% \mathrm{PPO}$ and $0.01 \%$ dimethyl POPOP.

Competition between peptides during uptake. The competition approach of Payne (1968), which assumes that structurally diverse peptides should compete during entry if Pseudomonas possesses a single transport system, was used. When an auxotroph is grown on a peptide that contains a required amino acid, any transport competition by another peptide, not containing such an essential residue, should deprive the auxotroph of a part of its needed nutrient and reduce growth. The auxotroph, depleted of reserves of essential amino acid, was inoculated into five samples of minimal medium containing: (i) peptide with the required amino acid as a residue, (ii) peptide with the required amino acid as a residue plus a potential competitor, (iii) required free amino acid, (iv) required amino acid plus potential competitor, or (v) a control of minimal medium only. In each experiment, any growth inhibition due to peptide competition was demonstrated by comparing (i) and (ii) and verified from the controls.

L-Histidine ammonia-lyase (EC. 4.3.r.3) was assayed by the method of Lessie \& Neidhardt (1967). 
Table I. Growth of P. putida auxotrophs in minimal medium

\begin{tabular}{|c|c|c|}
\hline Auxotroph & $\begin{array}{l}\text { Supplement } \\
(0.1 \text { to } 0.5 \mathrm{~mm})\end{array}$ & $\begin{array}{l}\text { Mean } \\
\text { generation } \\
\text { time* (h) }\end{array}$ \\
\hline his & $\begin{array}{l}\text { Ser-His-Asp } \dagger \\
\text { Gly-His-Gly } \\
\text { His-His } \\
\text { Ala-His } \\
\text { His-Gly } \\
\text { His }\end{array}$ & $\begin{array}{l}1 \cdot 9 \\
1 \cdot 5 \\
1.5 \\
1.6 \\
2 \cdot 0 \\
1 \cdot 3\end{array}$ \\
\hline met & $\begin{array}{l}\text { Met-Gly-Met-Met } \\
\text { Met-Gly-Gly } \\
\text { Gly-Met-Gly } \\
\text { Gly-Gly-Met } \\
\text { Gly-Met } \\
\text { Met }\end{array}$ & $\begin{array}{l}3 \cdot 5 \\
1 \cdot 0 \\
1 \cdot 0 \\
1 \cdot 1 \\
1 \cdot 0 \\
1 \cdot 0\end{array}$ \\
\hline$t h r$ & $\begin{array}{l}\text { Thr-Gly-Gly } \\
\text { Thr }\end{array}$ & $\begin{array}{l}3.4 \\
1 \cdot 7\end{array}$ \\
\hline $\operatorname{trp}$ & $\begin{array}{l}\text { Ala-Trp } \\
\operatorname{Tr} p\end{array}$ & $\begin{array}{l}1 \cdot 6 \\
1 \cdot 4\end{array}$ \\
\hline
\end{tabular}

RESULTS

Growth of P. putida on peptides

Absence of extracellular peptidase activity in P. putida (Cascieri \& Mallette, 1976) indicates that a peptide entered the organism when it satisfied the amino acid requirement of a mutant strain. Therefore, growth response offers a direct measure of uptake of various peptides by mutants of $P$. putida. Table $\mathrm{I}$ indicates that peptide transport and hydrolysis systems exist and meet the nutritional requirements of this organism.

\section{Dipeptide uptake}

Growth of $P$. putida met on glycylmethionine is equivalent to that on a mixture of methionine and glycine (Fig. 1). Moreover, if structurally different peptides were to enter $P$. putida by a single dipeptide transport system, then competition for entry should occur among these peptides. All functioning peptide transport systems were subject to competition between pairs of suitable peptides (Fig. 1). Free glycine, leucine or alanine (10: I molar excess) had no effect on growth of $P$. putida met on glycylmethionine. Yet corresponding dipeptides, glycylglycine, leucylleucine and alanylalanine depressed growth markedly (Fig. 1). Therefore, peptide uptake and amino acid uptake were distinct, as in E. coli (Cohen \& Rickenberg, 1956) and S. typhimurium (Ames et al., 1973).

Concentration of competing leucylleucine was related to growth inhibition (Fig. 2). Presumably, competition by leucylleucine limited the number of permease sites on the cell available for use by glycylmethionine. In similar studies with $P$. putida met (Table 2), a variety of other dipeptides and amino acids was tested for competition with uptake of glycylmethionine (O. I $\mathrm{mm}$ ).

To decide whether dipeptide transport was inducible or constitutive, two $P$. putida met cultures were grown separately on $0.1 \mathrm{~mm}$-glycylmethionine and $0.1 \mathrm{mM}$-methionine plus glycine, harvested, washed and exhausted of any residual methionine reserves. Equal portions of each culture were added to fresh samples of $0.1 \mathrm{~mm}$-glycylmethionine in minimal 


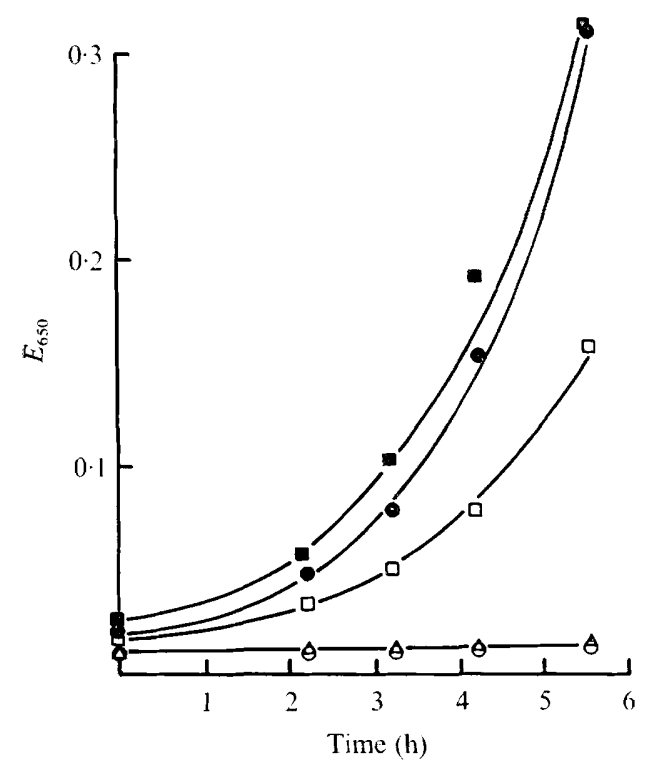

Fig. I

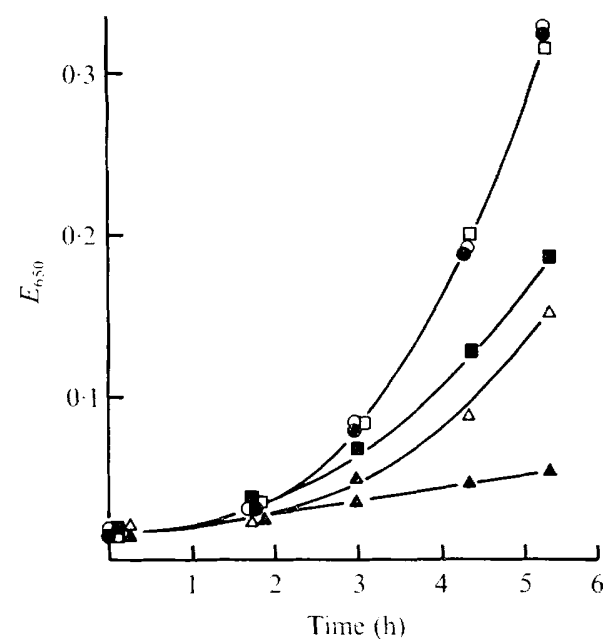

Fig. 2

Fig. I. Competition between glycylmethionine and other dipeptides during uptake. Pseudomonas purida met was grown on $0 \cdot 12 \mathrm{~mm}$-glycylmethionine $(\bullet)$ plus glycylglycine $(\square)$, leucylleucine $(\Delta)$ or alanylalanine (O), each at $1 \cdot 2 \mathrm{~mm}$, and also on methionine plus glycine (both $\left.0 \cdot \mathrm{I}_{2} \mathrm{~mm}\right)(\mathbf{D})$. Growth followed by extinction at $650 \mathrm{~nm}$.

Fig. 2. Dependence of growth inhibition on the concentration of competing dipeptide. Pseudomonas putida met was grown on $0.12 \mathrm{~mm}$-glycylmethionine alone $(0)$ or with added competitor leucylleucine: $0.60 \mathrm{~mm}(\boldsymbol{\Delta}) ; 0.30 \mathrm{~mm}(0)$, or $0.12 \mathrm{~mm}(\boldsymbol{\Delta})$. No competition was shown in cultures with either $0.12 \mathrm{~mm}$-glycylmethionine plus $\mathrm{I} \cdot 2 \mathrm{~mm}$-benzyloxycarbonylglycylglycine or benzyloxycarbonylleucylleucine ([i), or with $0.12 \mathrm{~mm}$-methionine and glycine plus $0.60 \mathrm{~mm}$-leucylleucine $(0)$.

Table 2. Summary of the amino acids and peptides which competed with the uptake of glycylmethionine $(0.1 \mathrm{~mm})$ in Pseudomonas putida met

\begin{tabular}{|c|c|c|}
\hline Class of compound added & $\begin{array}{l}\text { Compounds } \\
\text { showing } \\
\text { competition }\end{array}$ & $\begin{array}{l}\text { Compounds showing } \\
\text { no competition }\end{array}$ \\
\hline Amino acids $(\mathrm{I} \cdot \mathrm{O} \mathrm{mm})$ & None & $\begin{array}{l}\text { Gly, Ala, Val, Leu } \\
\text { Ile, Ser, Thr }\end{array}$ \\
\hline Dipeptides $(0.5$ to $1.0 \mathrm{~mm})$ & $\begin{array}{l}\text { Gly-Gly } \\
\text { Ala-Ala } \\
\text { Leu-Leu } \\
\text { Ala-Gly } \\
\text { Gly-Ala } \\
\text { Ala-His } \\
\text { Pro-Lys } \\
\text { Phe-Gly } \\
\text { Lys-Lys } \\
\text { Gly-Pro }\end{array}$ & $\begin{array}{l}\text { Gly-Gly-OEt } \\
\text { BZC-Gly-Gly } \\
\text { BZC-Leu-Leu } \\
\text { D-Leu-L-Leu } \\
\text { L-Leu-D-Leu } \\
\text { Gly- } \beta \text {-Ala } \\
\beta \text {-Ala-His } \\
\text { Gly-Sarcosine }\end{array}$ \\
\hline Oligopeptides ( $\cdot 0 \mathrm{~mm})$ & None & $\begin{array}{l}\text { Leu-Leu-Leu } \\
\text { Lys-Lys-Lys } \\
\text { Gly-Gly-Gly }\end{array}$ \\
\hline
\end{tabular}




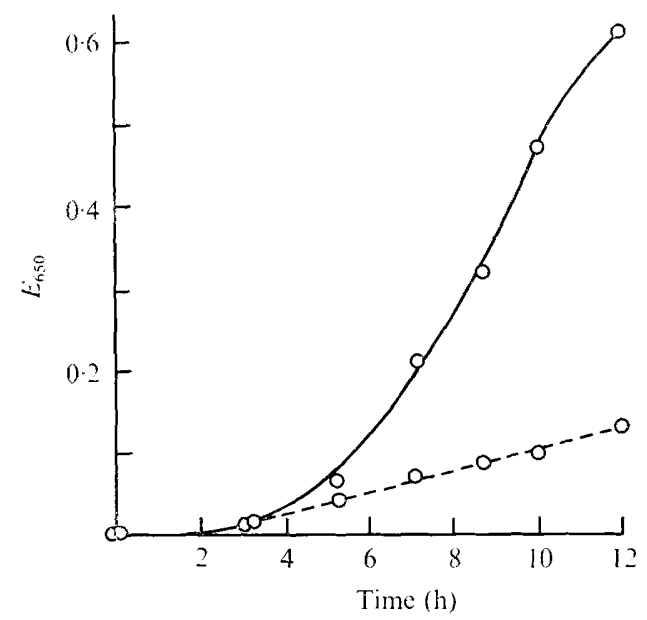

Fig. 3

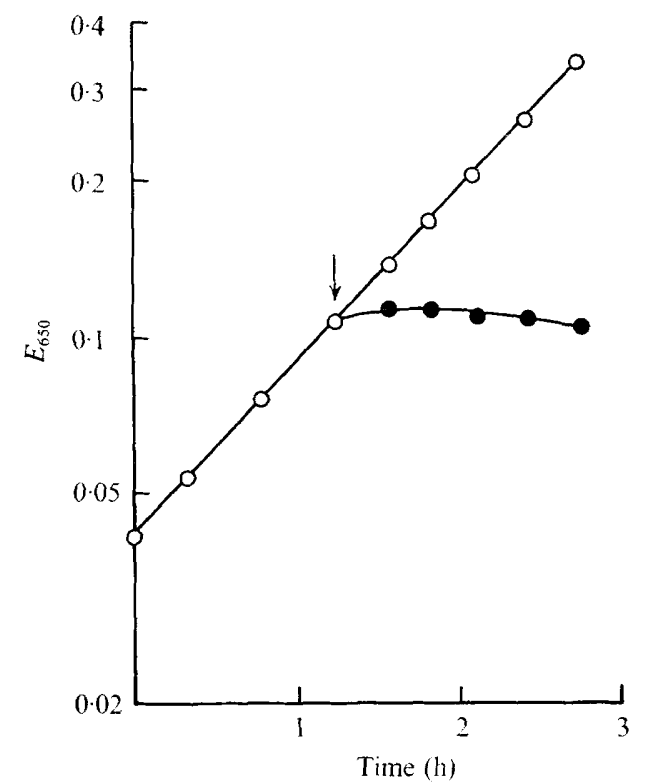

Fig. 4

Fig. 3. Role of C-terminal carboxyl in dipeptide uptake. Pseudomonas putida met was grown on either O.I mM-glycylmethionine (solid line) or O.I mM-glycylmethionine ethyl ester (broken line).

Fig. 4. Distinction between dipeptide transport and oligopeptide transport. Pseudomonas putida met was grown on 0.1 mM-glycylmethionine to an $E_{650}$ of 0.11 as indicated by the arrow. Then, either I.O mM-leucylleucine (๑) or I.O mm-leucylleucylleucine $(\bigcirc)$ was added and incubation continued.

medium and incubated. As growth of both cultures began immediately and continued at the same exponential rate, dipeptide transport must be constitutive in this organism as it is for E. coli (Payne \& Gilvarg, 1971).

\section{$N$-terminal amino and $C$-terminal carboxyl groups in peptide transport}

Since $\alpha$ - $N$-acetylglycylmethionine was not hydrolysed (Cascieri \& Mallette, 1976) by intracellular peptidases of $P$. putida, it could not be used to test the function of the $N$-terminal $\alpha$-amino group in dipeptide transport. However, neither benzyloxycarbonylleucylleucine nor benzyloxycarbonylglycylglycine (see Fig. 2) inhibited growth on glycylmethionine and thus they could not have been transported by the dipeptide system. Both corresponding unblocked peptides inhibited growth of $P$. putida met on glycylmethionine (Fig. I), yet prolyllysine competed with glycylmethionine for uptake (Table 2). Therefore, the requirement is probably for a protonatable rather than for a primary amino group in dipeptide transport as has been reported for E. coli by Payne (I974).

When $P$. putida met grew on glycylmethionine ethyl ester it had a generation time of $6 \cdot 7 \mathrm{~h}$ while with glycylmethionine (also at $0.1 \mathrm{mM}$, Fig. 3 ) the generation time was $\mathrm{I} h$. The growth curve for glycylmethionine ethyl ester was arithmetic, although $P$. putida can efficiently hydrolyse it to amino acids (Cascieri \& Mallette, 1976). Slow passive diffusion of the ethyl derivative into cells probably took place, followed by intracellular hydrolysis. Furthermore, glycylglycine ethyl ester did not compete with glycylmethionine for uptake in an 8: I molar ratio, while glycylglycine used in the same ratio was a competitor. We conclude that dipep- 


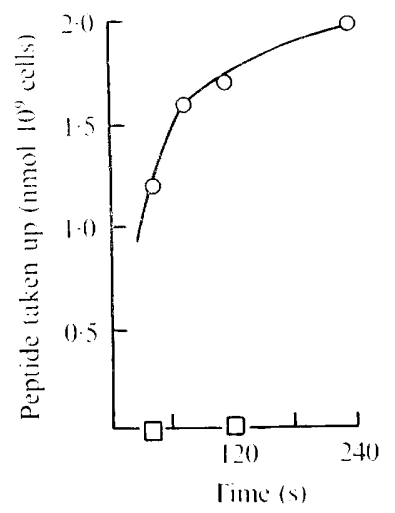

Fig. 5. Uptake of glycylglycyl[ $\left[-{ }^{14} \mathrm{C}\right]$ alanine by $P$. putida. Pseudomonas putida was washed, suspended to $2.5 \times 10^{9}$ bacteria/ml, incubated for 30 min at $25^{\circ} \mathrm{C}$, and peptide $(O)$ or peptide plus 2,4-dinitrophenol ( $\square$ ) was added. At designated times, $2 \mathrm{ml}$ portions were collected by filtration, washed, dried, and ${ }^{14} \mathrm{C}$ counted. A control containing peptide without cells yielded filters having only background radioactivity.

tide ethyl esters are not transported by the dipeptide system, which agrees with published reports for E. coli (Payne, 1974; Kessel \& Lubin, 1963).

\section{Distinction between transport of dipeptides and oligopeptides}

Since tripeptides can be considered dipeptides with their C-terminal carboxyl groups blocked, they might not compete with the dipeptides for uptake. Using the competition method, this hypothesis was shown to be correct (Fig. 4). Pseudomonas putida met cells were grown on $0.1 \mathrm{~mm}$-glycylmethionine, and then leucylleucine (I $\mathrm{mm}$ ) was added to one sample and leucylleucylleucine (1 $\mathrm{mm}$ ) to another. The dipeptide competed quickly and strongly with glycylmethionine, but the tripeptide did not. When methionine plus glycine (both at $0.1 \mathrm{mM}$ ) were "substituted for glycylmethionine, growth was not inhibited by subsequent addition of either leucylleucine or leucyiteucylleucine. In similar experiments (see Table 2) other tripeptides did not compete with glycylmethionine for uptake. These results suggest that $P$. putida has two different systems, one for uptake of dipeptides, another for oligopeptides. Confirmation from genetic studies like those in E. coli (Payne \& Gilvarg, I968a) would be desirable. A permease could be specific for dipeptides by binding properlyspaced free $\mathrm{N}$-terminal amino and $\mathrm{C}$-terminal carboxyl groups to specific sites on its surface.

\section{Stereo- and structural specificities in peptide transport}

Stereospecificity in dipeptide transport was confirmed by growing $P$. putida met on glycylmethionine $(0.12 \mathrm{~mm})$ with the following peptides $(0.60 \mathrm{~mm})$ added: L-leucyl-L-leucine, D-leucyl-L-leucine, and L-leucyl-D-leucine. Since growth was inhibited (Table 2) only by L-leucyl-L-leucine, the dipeptide transport system is stereospecific for both residues of the dipeptide. Peptidases of $P$. putida have similar specificities and cleave only L-leucyl-Lleucine of this group (Cascieri \& Mallette, 1976).

Finally, in competition studies intended to define additional structural requirements for dipeptide transport, glycyl- $\beta$-alanine, $\beta$-alanylhistidine and glycylsarcosine were tested as potential competitors of glycylmethionine. They were included in molar ratios ranging from 5: I to I0:I relative to glycylmethionine. None of the three competed with glycylmethionine, while glycylalanine, alanylhistidine and glycylglycine did inhibit growth (Table 2). 


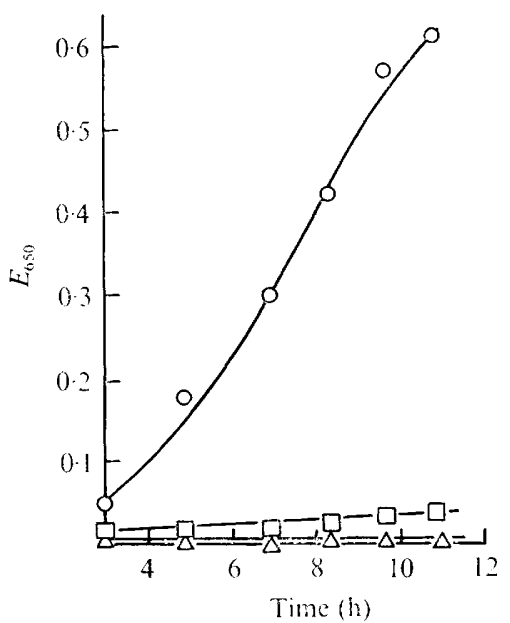

Fig. 6

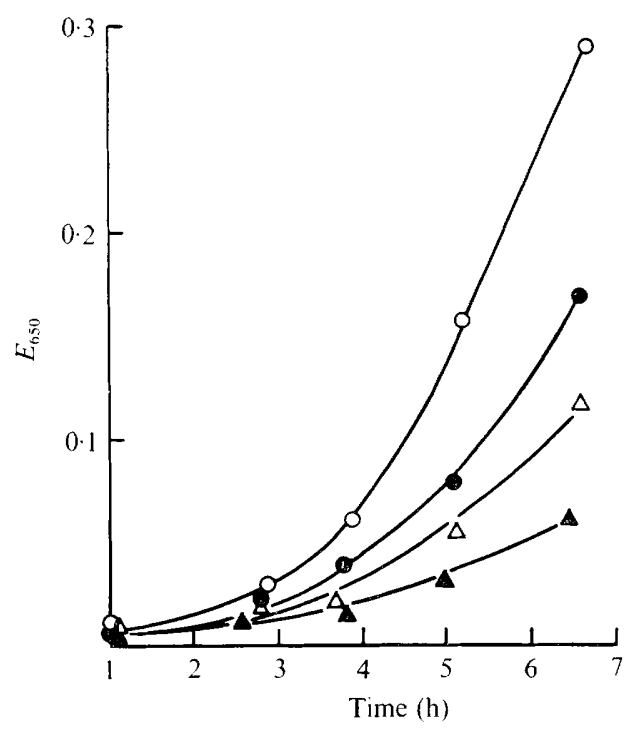

Fig. 7

Fig. 6. Inhibition of $P$. putida met by glycylglycyl-p-fluorophenylalanine. Inocula of $P$. putida met were added to o. I mM-methionine in minimal medium (O) plus either $0.5 \mathrm{~mm}$-glycylglycyl-p-fluorophenylalanine $(\square)$ or $0.5 \mathrm{~mm}$-p-fluorophenylalanine $\left({ }_{\triangle}\right)$.

Fig. 7. Side-chain specificity in oligopeptide transport. Pseudomonas putida met was grown on $0.1 \mathrm{~mm}$-glycylmethionylglycine $(\bigcirc)$ plus the following competing tripeptides $(0.5 \mathrm{~mm})$ : lysyllysyllysine $(\bullet)$, serylhistidylaspartate $(\triangle)$, threonylglycylglycine, alanylglycylglycine and glycylglycylglycine, (all represented by $(\boldsymbol{A})$. Growth in $0.1 \mathrm{~mm}$-methionine plus $0.2 \mathrm{~mm}$-glycine is also indicated by $(0)$.

\section{Oligopeptide uptake by P. putida}

The rate of uptake of glycylglycyl $\left[\mathrm{I}^{-14} \mathrm{C}\right]$ alanine $(0.08 \mathrm{~mm})$ by $P$. putida was initially rapid but declined after 2 min (Fig. 5). This behaviour corresponds to uptake of radioactive dipeptides and oligopeptides by E. coli (Kessel \& Lubin, 1963; Smith, Archer \& Dunn, 1970) and is strong evidence that oligopeptide uptake is constitutive. Addition of $5 \mathrm{~mm}-2,4^{-}$ dinitrophenol (an uncoupler of active transport) blocked uptake.

\section{Growth inhibition and stimulation by oligopeptides}

There is additional evidence for oligopeptide uptake when a peptide containing an inhibitory amino acid analogue inhibits growth. Uptakeof glycylglycyl-D,L- $p$-fluorophenylalanine followed by its intracellular hydrolysis would release L-p-fluorophenylalanine into the cytoplasm, which being an analogue of phenylalanine would cause formation of nonfunctional proteins (Fowden, Lewis \& Tristram, 1967). Growth of $P$. putida met in minimal medium, containing $O \cdot I \mathrm{~mm}$-methionine (to satisfy the auxotrophy) and either glycylglycyl$D, L-p$-fluorophenylalanine or D,L-p-fluorophenylalanine at 0.1 to $0.5 \mathrm{mM}$, was inhibited as expected (Fig. 6), and similar results were obtained in experiments on solid medium.

The growth curve (Fig. 7) of $P$. putida met on either 0.1 mM-glycylmethionylglycine or an equivalent mixture of free amino acids shows that this mutant could grow equally well in either system. In addition, $P$. putida his and thr used nutrient tripeptides for growih with generation times up to twice those on free amino acids (Table I).

These results could be explained by extracellular hydrolysis of peptides, followed by a 


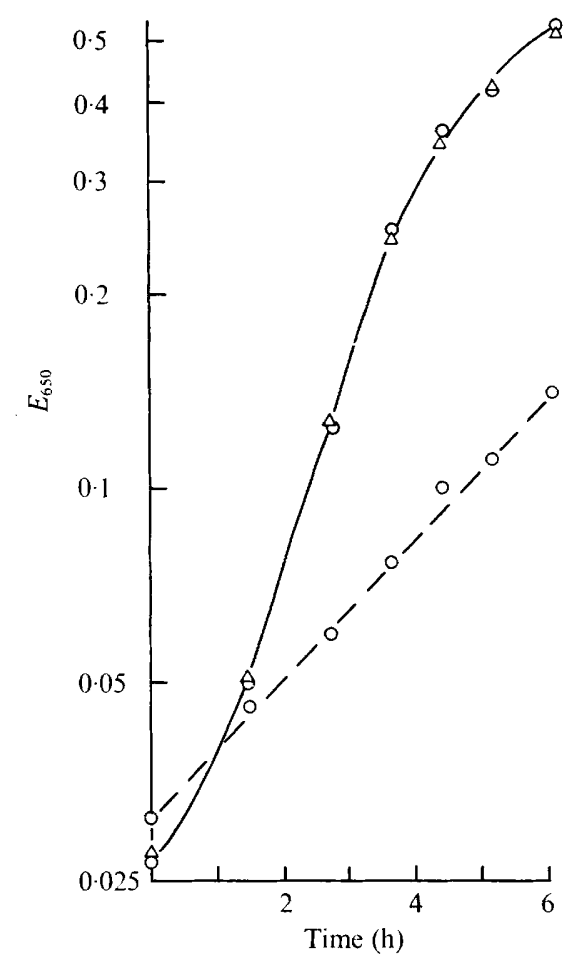

Fig. 8

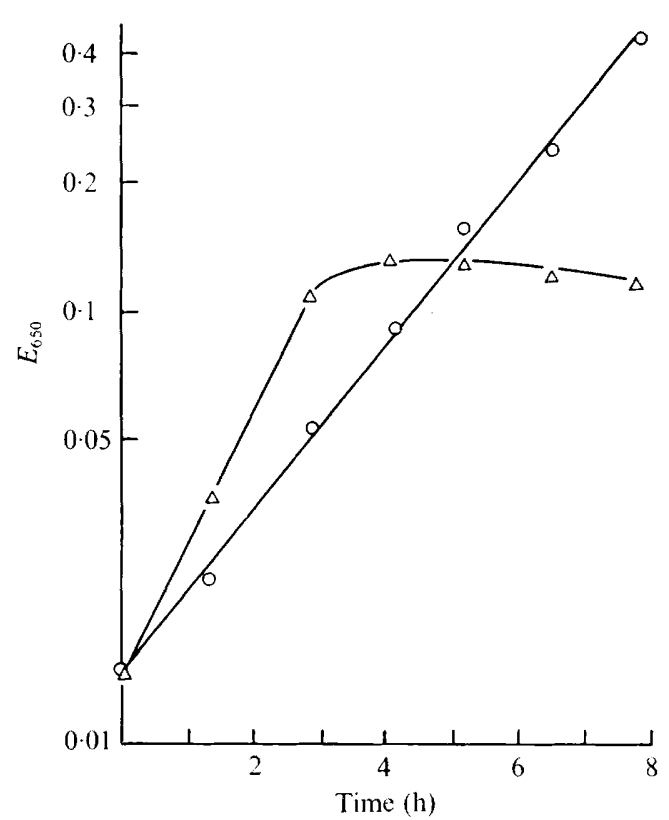

Fig. 9

Fig. 8. Terminal amino and carboxyl groups in oligopeptide transport. Pseudomonas putida met was grown on $0.1 \mathrm{~mm}$-glycylmethionylglycine (solid line) or $0.1 \mathrm{~mm}$-glycylmethionylglycine ethyl ester (broken line). $\angle$, cultures containing I mM-benzyloxycarbonylglycylglycylglycine plus $0.1 \mathrm{~mm}-$ glycylmethionylglycine.

Fig. 9. Growth of P. putida his on $0.5 \mathrm{~mm}$-histidine (. ) or $0.25 \mathrm{~mm}$-histidylhistidine ( 0 ). After $10 \mathrm{~h}$, growth reached an extinction of 1 with the peptide.

rapid uptake of hydrolysis products. However, this is unlikely, because subcellular fractionation (Cascieri \& Mallette, 1976) indicated an intracellular location for peptidases, and hydrolysis products could not be detected in solution when washed, whole bacteria were incubated with peptides in the absence of an energy source to support a rapid, sustained removal of hydrolysis products by active transport.

\section{Side-chain effects on oligopeptide uptake}

Structural specificities of oligopeptide uptake were also investigated, by the competition method. There was no competition by glycine, leucine or lysine (1.0 mM) for uptake of glycylmethionylglycine (0.1 $\mathrm{mm})$. A variety of tripeptides $(0.5 \mathrm{~mm})$ of different charge and structure did however, compete with the uptake of glycylmethionylglycine (0.1 mm) by $P$. putida met (Fig. 7), and in similar studies, growth of $P$. putida his on serylhistidylaspartate or glycylhistidylglycine was inhibited by glycylglycylglycine and glycylmethionylglycine, respectively, thus demonstrating that there was indeed only one oligopeptide uptake system.

Naider et al. (1974) reported that the position of the methionine residue in tripeptides affected their uptake by $S$. cerevisiae met, but no such preference was observed when 
$P$. putida met was grown separately on glycylglycylmethionine, glycylmethionylglycine and methionylglycylglycine (Table I).

\section{$N$-terminal amino and $C$-terminal carboxyl groups in oligopeptide transport}

Benzyloxycarbonylglycylglycylglycine ( $1 \cdot 0 \mathrm{~mm}$ ) did not compete with 0.1 mM-glycylmethionylglycine (Fig. 8), showing that terminal $\mathrm{N}$-acylation prevented oligopeptides from competing with simple tripeptides for the permease.

Pseudomonas putida met grew on glycylmethionylglycine ethyl ester with a generation time of $3 \cdot \mathrm{I} h$, whereas on glycylmethionylglycine the generation time was $\mathrm{I} h$ (Fig. 8). Thus, a free terminal carboxyl group improves oligopeptide uptake but is not so important as it was in dipeptide uptake. Pseudomonas putida possessed adequate peptidase activity toward glycylmethionylglycine ethyl ester (Cascieri \& Mallette, 1976).

\section{Stereospecificity and peptide size in oligopeptide uptake}

L-Leucylglycylglycine ( $1.0 \mathrm{~mm}$ ) competed with glycylmethionylglycine (O.I mM) while D-leucylglycylglycine ( $\mathrm{I} \cdot \mathrm{O} \mathrm{mm}$ ) did not, so that substitution of a $\mathrm{D}$ for an $\mathrm{L}$ residue on the N-terminal position prevents entry of oligopeptides.

All unmodified methionine peptides tested to this point were used by $P$. putida met as effectively as free methionine. However, the tetrapeptide methionylglycylmethionylmethionine supported a lower growth rate (mean generation time $3.5 \mathrm{~h}$ ) than normal (I h) (Table I). This reduction in growth rate may indicate that the upper size limit for transportable peptides was being approached. Peptidase activity on this tetrapeptide was at the same level as that for shorter methionine peptides (Cascieri \& Mallette, I976); poor hydrolysis was therefore not the cause of poor growth, which could only be attributed to transport. In E. coli, an upper size restriction for oligopeptide transport depended on the hydrodynamic volumes of oligopeptides (Payne \& Gilvarg, I968b).

\section{Yields of P. putida grown on histidine and histidyl peptides}

Pseudomona putida his produced 5- to ro-fold higher yields of bacteria when grown on a histidine-containing dipeptide or oligopeptide than it did on free histidine (Fig. 9). The difference may be explained as the result of histidase action. Pseudomonas putida his bacteria were subcultured from a stock slant into medium containing added histidine to adapt them to liquid culture, and a large amount of L-histidine ammonia-lyase (histidase) was produced during this period (specific activity $99 \mathrm{nmol}$ urocanate produced $/ \mathrm{min} / \mathrm{mg}$ protein). These inocula were added to media containing free histidine, which was probably concentrated within $P$. putida cells by amino acid transport and then catabolized by histidase. This enzyme has a $K_{m}$ in the mm range and binds its substrate less strongly than the protein-synthesizing system.

This series of steps results in exponential growth of $P$. putida his until histidine becomes limiting. As expected, after growth had stopped (shown by the levelling off in Fig. 9), histidine could not be detected in the medium. The final bacterial yield increased as the concentration of free histidine in the medium was increased; final extinctions were as follows: on $0.5 \mathrm{~mm}$-histidine, 0.14 ; on $1.0 \mathrm{~mm}, 0.22$; on $5.0 \mathrm{~mm}$, approximately $\mathrm{I} \cdot 0$. Conversely, when media with histidine in dipeptide or tripeptide form were inoculated, peptide was concentrated by peptide uptake systems and hydrolysed intracellularly by peptidase. The histidine released was used primarily for growth by the protein-synthesizing system which operates with a $K_{m}$ of $\mu \mathrm{M}$ order. Thus, the amount of free histidine (available after peptide hydrolysis and during protein synthesis) was well below the mu level necessary for 
efficient histidase action. Relatively poor cleavage of histidylhistidine by $P$. putida peptidase (Cascieri \& Mallette, 1976) supports this hypothesis. This type of protection of amino acids in peptides from catabolism has been reported for other micro-organisms (Gale, I945; Kihara, Klatt \& Snell, 1952).

\section{Peptide uptake by P. maltophilia}

The methionine-requiring pathogen $P$. maltophilia, a species of different ecological origin from $P$. putida, had the following generation times (h) for growth on methionine and methionine peptides at 0.1 to $0.2 \mathrm{~mm}$ : methionine, 2.5 ; glycylmethionine, 2.5 ; glycylmethionylglycine, 2.5; methionylglycylmethionylmethionine, $4 \cdot 9$. As with $P$. putida, generation times on methionine di- and tripeptides equalled those on free methionine. The tetrapeptide doubled the generation time, suggesting that $P$. maltophilia also possesses a size limit for peptide uptake. Glycylglycyl-D,L-p-fluorophenylalanine (0.05 mM) inhibited growth of $P$. maltophilia. While results are similar to those for $P$. putida (Cascieri \& Mallett, 1976), further investigations are needed to locate the peptidases required for peptide hydrolysis. The extracellular protease of this organism would not cleave peptides to amino acids, since such enzymes normally require blocked $\mathrm{C}$ - and $\mathrm{N}$-terminal residues in order to act on small peptide substrates (Morihara, Tsuzuki \& Oka, I968).

\section{DISCUSSION}

The specificities of the peptide uptake systems of $P$. putida are similar to those of other Gram-negative bacteria (Ames et al., 1973; Payne \& Gilvarg, 1971). This knowledge could be applied to: (i) transport of otherwise impermeant antimetabolites or metabolic intermediates into Pseudomonas as peptide derivatives, (ii) differentiation between Pseudomonas transport mutants and metabolic mutants and (iii) investigation of the role of $P$. putida in the soil. Systems for utilization of peptides by P. maltophilia appear similar to those of P. putida, although additional data would be necessary to confirm this.

Payne (1973) reported that dipeptides containing $\beta$-alanyl residues were concentrated poorly by $E$. coli, with the exception of $\beta$-alanylhistidine (carnosine). Because of the natural occurrence of carnosine in the gut from digests of animal skeletal muscle, he postulated that a separate system for uptake of this substrate would benefit $E$. coli. In $P$. putida, carnosine and other dipeptides containing $\beta$-alanine were not transported, as might be expected.

Failure to transport glycylsarcosine, as contrasted with transport of glycylproline, may be because transport of peptides with $N$-methylated peptide bonds confers no nutritional advantage, since $P$. putida lacks enzymes able to cleave methylated peptide bonds (Cascieri \& Mallette, 1976). Also, P. putida in its natural habitat will encounter only protein degradation products, which will not generally contain secondary amino acid except for peptides with prolyl or hydroxyprolyl residues. This rationale does not, however, explain how a dipeptide permease might differentiate between glycylsarcosine and glycylproline.

An evolutionary kinship among Gram-negative bacteria may account for similarities in their transport properties. Eucaryotes also possess mechanisms for peptide uptake, but, as might be expected, these systems differ from those of $P$. putida and the other procaryotes which have been studied. Naider et al. (1974) reported that a number of $N$-acetylated and t-butyloxycarbonyl peptides of methionine supported growth of a $S$. cerevisiae methionine auxotroph. In contrast, an acylated $\mathrm{N}$-terminal amino group prevented uptake by $P$. putida.

Soil contains up to $8 \%$ dry wt protein (Waksman, I932), derived from plant, animal and microbial materials. These proteins are broken down in several ways, e.g. by extracellular 
microbial proteases (Beck, 1968), and could provide usable concentrations of peptides for $P$. putida. Peptide utilization by Bacillus megaterium (another soil inhabitant) has also been suggested by Payne (1968). Although $P$. maltophilia occurs in quite different environments (e.g. pus, contaminated tissue cultures and wounds), all of these will provide protein. This species secretes its own extracellular protease and degrades host proteins to peptides (Stanier, Palleroni \& Doudoroff, I966) which could then be taken up and subsequently hydrolysed. However, Stanier et al. (1966) found it difficult to reconcile the widespread occurrence of $P$. maltophilia with its methionine requirement. In our opinion, given an extracellular protease and a peptide transport system, the organism could grow well on methionine-containing peptides from the environment. In this connexion, Wolfinbarger \& Marzluf ( I974) showed that $N$. crassa uses a peptide transport system in conjunction with extracellular protease. On the other hand, E. coli does not synthesize an extracellular protease, but the digestive enzymes of its hosts provide peptides and amino acids which $E$. coli then transports. To summarize, peptide transport helps to complete the cycle of protein to peptide to amino acid to protein, and it might be efficient, in energy terms, to transport peptides rather than amino acids in free forms.

This work was partially supported by the Pennsylvania Agricultural Experiment Station.

\section{REFERENCES}

Ames, B. N., Ames, G. F., Young, J. D., Tsuchiya, D. \& Lecocq, J. (1973). Illicit transport: the oligopeptide permease. Proceedings of the National Academy of Sciences of the United States of America 70, $456-458$

Anderson, G. W., Zimmerman, J. E. \& Callahan, F. M. (1967). A reinvestigation of the mixed carbonic anhydride method of peptide synthesis. Journal of the American Chemical Society 89, 5012-5017.

BECK, T. (I 968). Microbiologie des Bodens, pp. 74, 40I and 402. Munich: Bayerischer Landwirtschaftverlag.

Brenner, M. \& Huber, W. (1953). Herstellung von $\alpha$-Aminosäureestern durch Alkoholyse der Methylester. Helvetica chemica acta $36,1109-1115$.

Britten, R. J. \& MCClure, F. T. (1962). The amino acid pool in Escherichia coli. Bacteriological Reviews 26, 292-335.

Burston, D. \& MATthews, D. M. (1972). Intestinal transport of dipeptides containing acidic and basic $\mathrm{L}$-amino acids and a neutral D-amino acid. Chemical Science 42, 4P.

CASCIERI, T. \& MAllette, M. F. (1976). Intracellular peptide hydrolysis by Pseudomonas putida and Pseudomonas maltophilia. Journal of General Microbiology 92, 296-303.

Cohen, G. N. \& Rickenberg, H. V. (1956). Concentration specifique réversible des amino acides chez Escherichia coli. Annales de l'Institut Pasteur 9r, 693-720.

Fickel, T. E. \& Gilvarg, C. (1973). Transport of impermeant substances in E. coli by way of oligopeptide permease. Nature New Biology 241, I61-I63.

Fowden, L., Lewis, D. \& Tristram, H. (1967). Toxic amino acids: their action as antimetabolites. Advances in Enzymology 29, 89-163.

Gale, E. F. (1945). The arginine, ornithine and carbon dioxide requirements of streptococci (Lancefield group D) and the relation to arginine dihydrolase activity. British Journal of Pathology 26, 225-233.

Guardiola, J., De Felice, M., Klopotowski, T. \& Iaccarino, M. (I974). Mutations affecting the different transport systems for isoleucine, leucine, and valine in Escherichia coli K-1 2. Journal of Bacteriology II7, 393-405.

Johnson, G. G., Morris, J. M. \& Berk, R. S. (1967). The extracellular protease from Pseudomonas aeruginosa exhibiting elastase activity. Canadian Journal of Microbiology 13, 7 I 1-719.

Kessel, D. \& LubIN, M. (I963). On the distinction between peptidase activity and peptide transport. Biochimica et biophysica acta 7I, 656-663.

Kihara, H., Klatt, O. A. \& SNell, E. E. (I952). Peptides and bacterial growth. III. Utilization of tyrosine peptides by Streptococcus faecalis. Journal of Biological Chemistry 197, 801-807.

Kustu, S. G. \& Ames, G. F. (1973). The hisP protein, a known histidine transport component in Salmonella typhimurium, is also an arginine transport component. Journal of Bacteriology 116, I07-I I3.

Lessie, T. G. \& NeidhardT, F. C. (1967). Formation and operation of the histidine-degrading pathway in Pseudomonas aeruginosa. Journal of Bacteriology 93, $1800-1810$.

Liu, P. V. (1966). The roles of various fractions of Pseudomonas aeruginosa in its pathogenesis. II. Effects of lecithinase and protease. Journal of Infectious Diseases 116, I I 2-I I6. 
Mtrrifield, R. B. \& Woolley, D. W. ( 1956 ). The synthesis of L-seryl-L-histidyl-L-leucyl-L-valyl-L-glutamic acid, a peptide with strepogenin activity. Journal of the American Chemical Society 78, 4646-4649.

Morihara, K., Tsuzuki, H. \& OKa, T. ( 1968 ). Comparison of the specificities of various natural proteinases from microorganisms. Archives of Biochemistry and Biophysics 123, 572-588.

NAIDER, F., BECKeR, J. M. \& KATZIR-KATChal.SKI, E. ( I974). Utilization of methionine-containing peptides and their derivatives by a methionine-requiring auxotroph of Saccharomyces cerevisiae. Journal of Biological Chemistry 249, 9-20.

PAYNE, J.W. (1968). Oligopeptide transport in Escherichia coli. Specificity with respect to side chain and distinction from dipeptide transport. Journal of Biological Chemistry 243, 3395-3403.

PAYNE, J. W. ( ( 973). Peptide utilization in Escherichia coli: studies with peptides containing $\beta$-alanyl residues. Biochemica et biophysica acta $\mathbf{2 9 8}, 469-478$.

PAYNE, J. W. (I974). Peptide transport in Excherichia coli: permease specificity towards terminal amino group substituents. Journal of General Microbiology 8o, 269-276.

PAYNe, J. W. \& Gilvarg, C. $(1968 a)$. The role of the terminal carboxyl group in peptide transport in Escherichia coli. Journal of Biological Chemistry 243, 335-340.

Payne, J. W. \& Gilvarg, C. (I 968 b). Size restriction on peptide utilization in Escherichia coli. Journal of Biological Chemistry 243, 6291-6299.

Payne, J. W. \& Gilvarg, C. (1971). Peptide transport. Advances in Enzymology 35, 187-244.

Sheehan, J. C., Preston, J. \& Cruickshank, P. A. (1965). A rapid synthesis of oligopeptide derivatives without isolation of intermediates. Journal of the American Chemical Society 87, 2492-2493.

Smith, R. L., Archer, E. G. \& Dunn, F. W. ( 970$)$. Uptake of $\left[{ }^{11} \mathrm{C}\right]$-labelled tri-, tetra-, and pentapeptides of phenylalanine and glycine by Escherichia coli. Journal of Biological Chemistry 245, 2967-2971.

Stanier, R. Y., Palleroni, N. J. \& Doudoroff, M. (1966). The aerobic pseudomonads: a taxonomic study. Journal of General Microbiology 43, 159-271.

Waksman, S. A. (1932). Principles of Soil Microbiology, p. 682. Baltimore: Williams and Wilkins.

Wolfinbarger, L. \& Marzluf, G. A. ( 1974 ). Peptide utilization by amino acid auxotrophs of Neurospora crassa. Journal of Bacteriology 119, 371-378. 